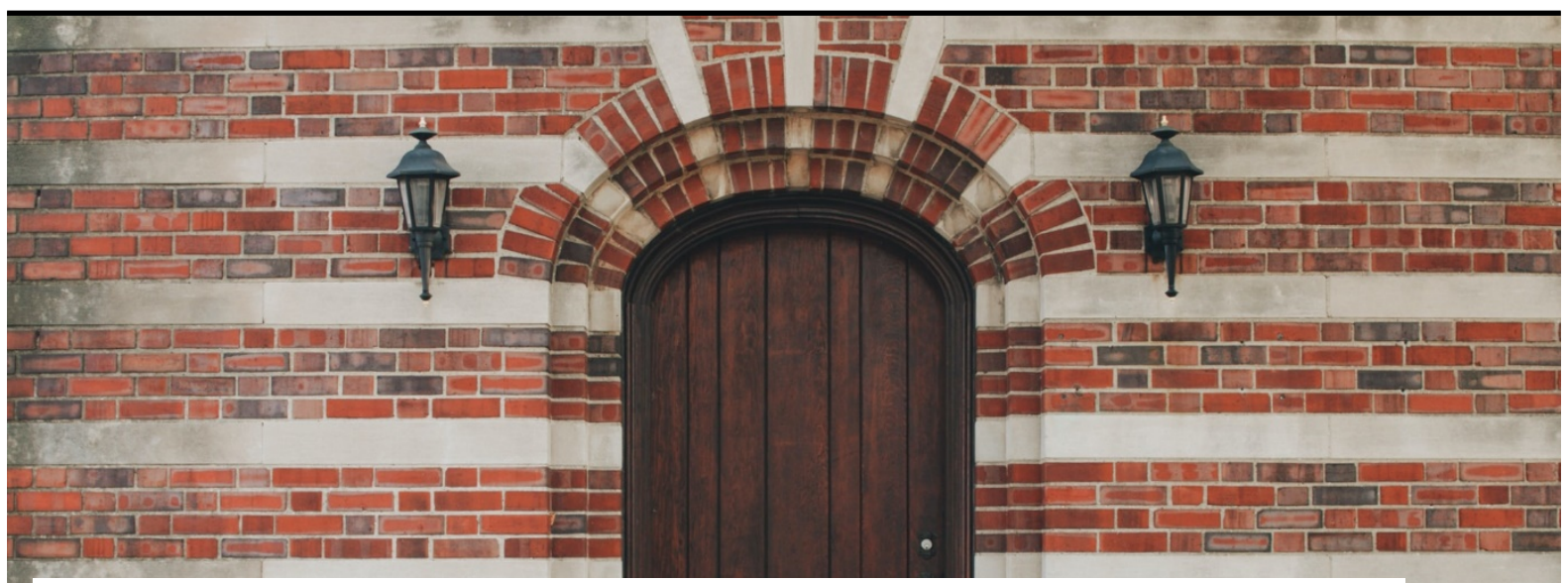

\title{
Do educators' responsibilities stop at the classroom door?
}

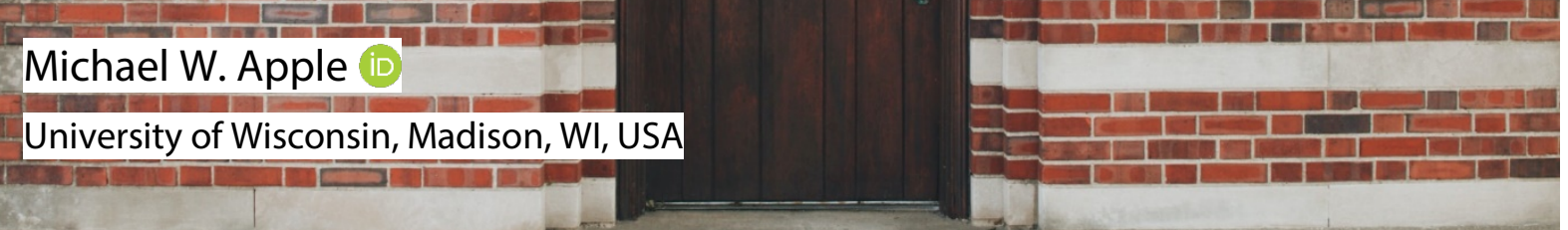

Photo by Brianna Santellan on Unsplash

\section{ABSTRACT}

Schools are crucial sites in the politics of social and cultural transformation. However, we should not limit our work to the internal structures, processes, and content of schooling. The struggles in schools should be organically connected to community-based struggles outside of schools. Therefore, critically democratic action in education needs to transform not only schools, but also the communities and societies in which these schools are situated. Actions in and around schools are even more powerful and long lasting when they are closely connected to real people and real movements and mobilizations outside as well as inside the places where so many of us work.

\section{KEYWORDS}

Democratic schools; justice; transformation; social action; community

For many critical educators, struggling in schools is crucial. Anyone who knows my work also knows that I believe that such efforts are essential. Indeed, as I argue in Can Education Change Society? (Apple 2013), schools are crucial sites in the politics of social and cultural transformation. However, limiting our work to the internal structures, processes, and content of schooling can also be problematic. It can lead to simple 'reformism' rather than what I have called 'non-reformist reforms.' The latter are actions that are deeply connected to larger mobilizations and politics and provide doors to further even more substantive critically democratic transformations not only in schools but also in the communities and societies in which these schools are situated. This is perhaps most visible in the growing commitment on the part of teacher unions in many nations to embrace social justice teacher unionism and to form alliances with transformative movements in local communities that deal expressly with the structures of inequality and injustice in those communities (Charney et al., 2021; Weiner, 2012).

These movements are significant for existing teachers and administrators. But this recognition is just as important for students in teacher education programs. With the retirement of a large percentage of teachers, and the exhaustion from the efforts to educate during a pandemic, those who take their place need to much more fully understand what is at stake in schools and 
communities and how organized bodies of teachers and other educators in an ever expanding coalition with progressive movements outside of schools can respond to these realities in critically democratic ways.

The recognition of the importance of these connected efforts is evident in the United States. The growing numbers of successful teacher strikes and collective mobilizations in Chicago, West Virginia, Los Angeles and elsewhere, and the existence of strong community support, document how one can blend together the dual commitments to teacher rights, respect, and autonomy and progressive social change (see, e.g., Blanc, 2019; Uetricht, 2014). Indeed, there is clear recognition by progressive teacher unions that the future will require even more social commitments to community needs and values and a commitment to put these larger social and economic needs at the forefront of teacher concerns. For example, the Chicago teacher union has taken up the struggle for affordable and respectful housing as a key part of their agenda. Similar commitments are visible throughout the nation and are very visible as well in places like Brazil and elsewhere.

Thus, it is increasingly clear that both locally and nationally these more expansive movements and alliances are providing models for a future where struggles in schools are organically connected to community-based struggles outside of schools. In critical educator and union activist Bob Peterson's words, they are increasingly guided by an enhanced understanding and commitment to the principles that underpin social justice unionism. As he puts it, 'A social justice lens should be omnipresent throughout al/ union work whether it is wages and working conditions, professional and pedagogical issues, internal union matters, or broader policy concerns' (Peterson, 2021, p. 100).

Let me stress that what I have said so far is based on a particular position-that the support of individual educators and organized bodies of teachers and the building of collective agendas and actions in order to work for the benefit of educators and local communities is not and should not only be based on a theoretical agenda, although the reasons for engaging in these action are deeply grounded in a robust politics of what Nancy Fraser (1997) has called redistribution, recognition, and representation. Such academic understandings are important of course. But as I have documented elsewhere, for many critically democratic educators the support is often grounded in intensely and deeply held experiences of being in schools, of engaging in the creative labor of developing powerful and responsive critical curricula, of building alliances with and being taught by the communities we are serving, and so much more (Apple et al., 2018).

In many ways, the arguments I have marshalled here provide us with examples of practical answers to one of the most pressing questions that guide critically democratic educational policies and practice-What role can education play in social transformation? This is a complex question, one I have weighed in on before (Apple, 2013). But all we need to do is look at what conservative movements, foundations, and media have been doing for years. For them, the role of culture, knowledge, and memory is central to their aim of moving people to the Right. They have focused on cultural themes-raising issues about critical race theory and 'appropriate' history, LGBTQI, climate change, god and women's roles, the family - as ways of bringing large groups of people under their leadership. Schools, museums, churches-each of these becomes a site of the creation of a conservative common-sense (see, for example, Apple, 2006; Oberlin 2020). And they have built a complex set of deeply connected alliances that tie struggles in schools directly to rightist economic, cultural, and political movements.

Thus, this is not new. In fact, building these relations is exactly what the Right has been doing for decades. The Right clearly recognizes the importance of winning at multiple levels and then connecting those victories to each other. The battles were over multiple issues-shrinking the state, reducing taxes on the affluent, destroying the power of unions, attacking progressive curricula, privatization, moving schools toward a goal of making them sources of profit, mobilizing (often faux) populist movements and conservative religious identities, and much more.

If you will forgive the military metaphors, what the Right has done-and what I am advocating for educators to do--is what Antonio Gramsci (1971) called 'a war of position.' This is a set of counter- 
hegemonic actions in which everything counts. Critically democratic action in education, in health care, in community lives, in paid and unpaid workplaces, in the family, in the disgraceful and racist forms of incarceration-all of these count. Action against dominant relations involving gender and sexuality, race, class, ability, age, environmental degradation all count. The task is to then work hard to connect these actions to each other and to build alliances across our differences so that the 'we' that is created is broader and more mutually supportive. Thus, the local counts, not only the regional and national. As I noted above, in Nancy Fraser's words, the politics of recognition and of representation count as well as a politics of redistribution (Fraser, 1997). And actions in and around schools are made more powerful and last longer when they are closely connected to real people and real movements and mobilizations outside as well as inside the places where so many of us work (Verma \& Apple, 2021). Individually and collectively committed educators at all levels can learn from this. Our work in schools is absolutely necessary. But our responsibilities and actions can't stop at the classroom door.

\section{Notes on contributor}

Michael W. Apple is John Bascom Professor Emeritus of Curriculum and Instruction and Educational Policy Studies at the University of Wisconsin, Madison and Professorial Fellow at the University of Manchester. Among his recent books are: Can Education Change Society?; The Struggle for Democracy in Education: Lessons from Social Reality, and Disrupting Hate in Education: Teacher Activists, Democracy, and Global Pedagogies of Interruption.

\section{ORCID}

Michael W. Apple (i) http://orcid.org/0000-0001-8459-8238

\section{References}

Apple, M. W. (2006). Educating the "right" way: Markets, standards, god, and inequality (2 ${ }^{\text {nd }}$ ed.). Routledge. Apple, M. W. (2013). Can education change society? Routledge.

Apple, M. W., Gandin, L. A., Liu, S., Meshulam, A., \& Schirmer, E. (2018). The struggle for democracy in education: Lessons from social realities. Routledge.

Blanc, E. (2019). Red state revolt: The teachers'strike wave and working class politics. Verso.

Charney, M., Hagopian, J. \& Peterson, B. (Eds.) (2021). Teacher unions and social justice: Organizing for the schools and communities our students deserve. Rethinking Schools.

Fraser, N. (1997). Justice interruptus. Routledge.

Gramsci, A. (1971). Selections from the prison notebooks. International Publishers.

Peterson, B. (2021). Social justice teacher unionism: What does it mean to fight for the schools and communities our students deserve? In M. Charney, J. Hagopian, \& B. Peterson (Eds.), Teacher unions and social justice (pp. 100-102). Rethinking Schools.

Oberlin, K. (2020). Creating the creation museum: How fundamentalist beliefs come to life. New York University Press.

Uetricht, M. (2014). Strike for America: Chicago teachers against austerity. Verso.

Verma, R. \& Apple, M. W. (2021). Disrupting hate in education: Teacher activists, democracy, and global pedagogies of interruption. Routledge.

Weiner, L. (2012). The future of our schools: Teachers unions and social justice. Haymarket Books. 